\title{
The Speech Act of Suggestion by Islamic Preachers (Da'i) in Dialogic Da'wah in the City of Surakarta
}

\author{
Miftah Nugroho \\ Universitas Sebelas Maret \\ Surakarta, Indonesia \\ miftahnugroho@gmail.com
}

\author{
Sri Samiati Tarjana \\ Universitas Sebelas Maret \\ Jl. Ir. Sutami, Surakarta, Indonesia
}

\author{
Dwi Purnanto \\ Universitas Sebelas Maret \\ Jl. Ir. Sutami, Surakarta, Indonesia \\ dwi.purnanto@yahoo.com
}

\begin{abstract}
This article describes the realization of speech acts suggestion expressed by the Islamic preachers (da'i(-s)) in responding to the questioners' (mad'u) questions. The data were obtained by employing the methods of nonparticipativeobservation and recording method. The data analysis used the method of ways and purpose. The obtained findings include the da'i expressed speech acts of suggestion into five distinguished forms, namely the imperatives, providing options, impersonal, hedging, and hints. The existing power and politeness factors surely affect the selection and use of the five distinguished types of speech acts suggestion.
\end{abstract}

Keywords-da'i; mad'u; dialogic da'wah; speech act of suggestion

\section{INTRODUCTION}

The study of language use in the field of Islamic preaching attract many researchers. From our personal review, there were13 studies examined the use of language in the da'wah domain, among others Ma'ruf (1999), Hidayat (1999), Subagyo (2000), Fakhrudin (2000), Maksan (2001), Atmawati (2002), Irawati (2004), Hadisaputra (2005), Sadhono (2005), Gusneti (2007), Atmawati (2009), Abdullah (2010), Sadhono (2011). Of those studies, there were not yet found a spesific discussion on the use of speech act of suggestion.

The act of suggestion concerns the act of expressing the offered suggestion to the speaking partners. The purpose of expressing this attitude is to suggest the speaking partners about things. In dialogic $d a$ 'wah, this speech acts are widely expressed by da' $i$ when they were answering the questions. The $d a^{\prime} i$ answers in addition to provide explanations, such typical expression can either be inferred as a request, prohibition, or advice. As a typical realization of anwers, such speech act is siginificant to be studied for these expressions reflect a sense of threatening discourse recipients or mad'u's face. To say threatening face, since this speech act limits the mad'u's action. In other words, by suggesting about things, it implies that one threaten the negative face of his speaking partners. Consequently, the dai will certainly try to mitigate or soften the sustainability of this speech act. Thus, this study would explain how to realize the speech act of providing a well-mannered suggestion in the frame of a dialogic preaching or da'wah discourse.

\section{LITERATURE REVIEW}

\section{A. The Speech act of suggestion}

Speech act is a basic term in linguistic studies, especially pragmatic fields. Predecessor of this term J.L. Austin (1962) through his work entitled How to do things with words. The basic concept proposed by Austin (1962) originally was to typify conative/constative and performative utterances. The constative utterance is an utterance expresses a statement. This related to right or wrong things being stated. Then, the performative utterance is intentionally expressed to have someone to do something. These utterances can never be judged in terms its correctness, however, the expression can be recogized whether or not the utterance is cosidered sound or valid. Another basic concept proposed by Austin (1962) in his understanding of speech acts is about distinguishing the acts of locution, illocution, and perlocution. The act of locution concerns a production of a meaningful linguistic expressions. Meanwhile, the act of illocutionary concerns the speaker's acts of illocution which present in the linguistic spoken expressions. The act of perlocution concerns expressing acts within the expressed linguistics features which go along with specific consequences or effects on the recipients.

The concept of speech acts was initially proposed by Austin which then revised and refined by his student, John Searle. Searle come up with a more perpect concept. Additionally Searle (1979) has successfully classified of various speech acts into five kinds, namely assertive or representative, directive, commissive, expressive. The assertive speech act is a type of speech act that demands the speaker to reveal the truth of his/her proposition. This speech acknowledges the speaker's confidence. Meanwhile, the directive speech act is a typical act in speech that expresses speaker's desire in order that the speaking partners would do something for him/her. In the meantime, the commissive act is a speech act that demands the speakers about the future acts. The expressive act is a speech act that 
suggests a psychological attitude or the speaker's statement of joy or sorrow and happy or displeased. The declarative speech act is an act produces by a speaker to changethe world.

The speech act of suggestion is an act within a speech that imply sub-speech act of directive act.The speech act of suggesting can only only be acceptable when it is expressed according to the felicity conditions.

Propositional content: Actions referring to future events.

Preparatory condition : Speakers have reason that the action to be produced can be profitable to themselyes is the command or though it may be unclear to both speakers and the speech partners that the speaker seech act of will take action under reasonable circumstances.
suggestion. Below is an example of a $d a$ ' $i$ 's utterance which

Sincerity condition: $\quad$ The speaker believes that the action will bierditittbiss/ther sipleadkitignanytnerosce that is used to suggest, Essential condition : It is as an attempt to provide effects of the interests .

The data in this study are the utterances expressed by $d a^{\prime} i$ in dialogical da'wah in Surakarta. Such utterances reflect a series of frequently asked questions between mad'u and $d a$ ' $i$ upon interacting in a question and answer (Q\&A) session. The selected speeches as data cover speeches reflect the acts of suggesting. The data is, therefore, considered authentic for they were obtained naturally in a reasonable communication event (speech). In other words, the data in the form of speech was actually the results of speeches without the researchers intervention or unaffected by the researcher's presence especially at the time of observing and recording language use of the research objects.

The data source is the dialogic Islamic preaching discourse or da'wah organized by Islamic organizations and non-Islamic mass organizations, whether located at home, in the offices, or in the mosques. The data sources in this article were taken from 14 dialogic da'wah locations, among others were the PCM Banjarsari, PCM Jebres, PCM Kota Bengawan, at MTA Branch Jebres 1, at MTA Branch Jebres 2, in MTA at Binaan Pasar Kliwon, at Asysyifa Assembly, in Jamaah Haji Arofah 92, in Jamaah Mrs. Annikmah, at the Al-hikmah Mosque, Al-furqon Mosque, Al-fajr Mosque, at the UNS Rectorate building, and at the house of Prof. Dr. Moch Fathoni, dr., Sp.JP (K).

The data in this article was primarily obtained through applying nonparticipative- observation method. The observations were accompanied by recording which is supported by a digital camera. After the data being collected, the next step was the classification and analysis of the data. The data analysis method applied the method of ways and purpose as proposed by Leech (1983). On presenting data, it was used both formal and informal methods as put forward by Sudaryanto (1993). although it.was delivered in imperative mode of utterance.

(1) Context: The $d a^{\prime} i$ expressed a speech acts of suggesting

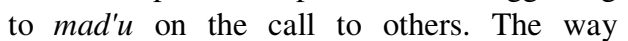
expressing such typical use of act in speech was found in a dialogic da'wah at the MTA Branch of Jebres 2.

\section{RESUlT AND Discussion}

On the results of the classified data which was conducted initially, it was found five typical acts of suggestion within $d a ' w a h$ in the city of Surakarta. The five types are imperative, optional, impersonal, hedging, and hint. Here is the presentation of the fifth types of speech acts suggestion.

Imperative Nah, coba panggil, panggil yang baik, kirakira tenar lagi nggak ya. Lha dipanggil buruk tenar, kalo dipanggil gitu tenar lagi. Kalau tadi ya terjadi di kalangan-kalangan yang orang yang tidak ngaji ya ya itulah budaya mereka.

At (1) there was a $d a^{\prime} i$ or an Islamic preacher's speech which reflecs the illocutionary force of suggesting, ie Nah, coba panggil, panggil yang baik, kira-kira tenar lagi nggak ya. Although this utterance was realized in an imperative form, the only act of suggesting is associated the illocutionary force. Based on the speech context, the purpose was to give advice to the discourse recipients or $m a d ' u$ to call the name of another person with a good name.

\section{Providing Optionality}

Providing options means that the $d a^{\prime} i$ delivers a typoical speech acts use of suggesting, to do so, the additional use of linguistic markers of words, are normally found. Here is an example of the speech act of suggestion indicated by an act of option giving.

(2) Context: The $d a^{\prime} i$ expressed a speech acts of suggesting to the mad'u about the call to others. The expressed speech acts was found in dialogic $d a$ 'wah at the MTA Branch Jebres 2.

Da'i: Ya gak jadi, gak jadi khusyu'. Kalau karpetnya wangi tu yo sudah thek, gitu sujud ya bisa khusyu' baca mau panjang mau ini. Apalagi kalau karpet, karpetnya gak blas ndak pernah bawa ke laundry ya sudah itulah ya. Maka kalau di mesjid-mesjid kita belum bisa seperti itu kalau kita di rumah ya tempat sholatnya itu yang nyaman ya. Nek 
kiro-kiro pengab yo dikei wayer opo AC bikin yang se.., nyaman, ojo kok shalat karo dibledehke klambine.

Ya tidak jadi, tidak jadi khusyu'. Kalau karpetnya wangi itu ya sudah thek, gitu sujud ya bisa khusyu' baca mau panjang mau ini. Apalagi kalau karpet, karpetnya tidak sama sekali tidak pernah bawa ke laundry ya sudah itulah ya. Maka kalau di mesjidmesjid kita belum bisa seperti itu kalau kita di rumah ya tempat sholatnya itu yang nyaman ya. Kalau kira-kira pengab ya diberi ya diberi kipas angin apa AC membuat yang se.., nyaman. Jangan kok shalat dengan dibuka bajunya.

On data (2) the utterance that reflects the illocutionary force of suggestion is Maka kalau di mesjid-mesjid kita belum bisa seperti itu kalau kita di rumah ya tempat sholatnya itu yang nyaman ya. The word use kalau 'if' shows that the $d a^{\prime} i$ provides choice to the mad' $u$ about a comfortable place of prostration, whether in the mosque or at home.

\section{Impersonal}

Impersonal means the speech acts of suggesting expressed by the $d a^{\prime} i$ realized in passive form. Below are examples of the speech acts suggestion which indicate the use of impersonal forms.

(3) Context: The $d a$ ' $i$ expressed a speech act of suggestion to the mad'u regarding the giving of zakat 'alm' which is prioritized to the nearest family or neighbor around. Such expressed speech act was found in a dialogic da'wah in PCM Kota Bengawan.

Da'i: Wong tuwane malah sugih ngungkuli aku og. Artinya cari yatim yang berhak menerima zakat. Utamanya masih famili ya, tapi bukan yang kita, menjadi tanggung jawab kita. Misalnya ada eee adik-adik atau balita yang yatim. Kita pelihara, kita nafkahi, kita biayai sekolahnya. Terus zakate tak nggo biayai. Ndak boleh. Karena itu menjadi tanggung, tanggungan kita. Jadi diutamakan memang famili tetapi yang tidak menjadi tanggungan kita. Kemudian meluasnya kepada tetangga, pada orang yang dekat dengan kita, terus sampek meluas kalau masih. Mungkin yang punya pabrik punya mall itu ngedum sekian banyak orang bisa itu- Ngoten nggih bu? Mangga!

Orang tua malah kaya melebihi saya kok. Artinya cari yatim yang berhak menerima zakat. Utamanya masih famili ya, tapi bukan yang kita, menjadi tanggung jawab kita. Misalnya ada eee adik-adik atau balita yang yatim. Kita pelihara, kita nafkahi, kita biayai sekolahnya. Terus zakate tak nggo biayai. Ndak boleh. Karena itu menjadi tanggung, tanggungan kita. Jadi diutamakan memang famili tetapi yang tidak menjadi tanggungan kita. Kemudian meluasnya kepada tetangga, pada orang yang dekat dengan kita, terus sampek meluas kalau masih. Mungkin yang punya pabrik punya mall itu membagi sekian banyak orang bisa itu. Begitu ya Bu? SilakanI

On data (3), the utterance that reflects illocutionary force of suggestion is on Jadi diutamakan memang famili tetapi yang tidak menjadi tanggungan kita. Kemudian meluasnya kepada tetangga, pada orang yang dekat dengan kita, terus sampek meluas kalau masih. The verb diutamakan shows that $d a^{\prime} i$ applied passive forms at the time expressing the speech acts of suggestion.

\section{Hedging}

Hedging in this context means the use of speech act of suggestion expressed by $d a^{\prime} i$ which can be observed from the linguistic markers use to save the speaker to reduce a sense of threatening to the speaker's participants, in order that the speaker would be perceived more polite. Below is an example of a speech act of suggestion which mitigate illocutionary force through hedging.

(4) Context: The $d a^{\prime} i$ expressed a speech acts of suggesting to the mad'u concerning the recomended location of slaughtering the sacrificial animals (hewan qurban). The expressed speech acts was found in a dialogic da'wah addressed in PCM Kota Bengawan.

Dai: Lha iya, sebentar. Kalau di masjid itu ada... ada segi negatifnya menjadikan bau mesjid tidak enak tidak sedap dan kita dianjurkan untuk memperwangi masjid kita. Jadi sebalik sebaiknya itu tidak di sekitar masjid. Tapi kalau ndak ada tempatnya, jadi malah bagus Pak kalau di...

In data (4), it was found a speech of suggesting that imply illocutionary force, which is Jadi sebalik sebaiknya itu tidak di sekitar masjid. The use of sebaiknya 'should' indicates that the $d a$ ' $i$ strategically applied the hedging form at the time he was expressing the speech act of suggesting.

\section{Hints}

Hints means speech act of suggestion which is expressed in a vague form that lead the mad'u's to speaculate in grasping the speaker's aims at lecturing. The following speech act indicate the use of hint form. 
(5) Context: The $d a^{\prime} i$ expressed the speech of suggestion to mad'u about the exemplary ahead of the employee. The expressed speech acts is found in dialogic da'wah at the Rectorate of UNS.

Dai: Bapak-bapak ini kan pimpinan, sama dengan kita-kita ini. Pimpinan itu kan dicontoh. Kalau kita ini teler ya, ini anak buah kita itu susah untuk kita, kita kita harapkan trengginas Pak. Mesti mesti akan teler semua. Walaupun sakitsakit, misalnya. Awake loro kabeh, itu ya kita seakan-akan ora loro kabeh sehat terus, Pak. Saya itu juga berusaha untuk sehat kadang-kadang walaupun rodo ngelu-ngelu sitik, di depan parapara apa anak buah. ... Sakit perut yo diempet, Pak.

Bapak-bapak ini kan pimpinan, sama dengan kitakita ini. Pimpinan itu kan dicontoh. Kalau kita ini teler ya, ini anak buah kita itu susah untuk kita, kita kita harapkan cekatan Pak. Mesti mesti akan teler semua. Walaupun sakit-sakit, misalnya. Badannya sakit semua, itu ya kita seakan-akan tidak sakit semua sehat terus, Pak. Saya itu juga berusaha untuk sehat kadang-kadang walaupun agak pusing sedikit, di depan para-para apa anak buah. ... Sakit perut ya ditahan Pak.

On data (5), the speech act of suggestions are realized in hint form through utterance Bapak-bapak ini kan pimpinan, sama dengan kita-kita ini. Pimpinan itu kan dicontoh. Kalau kita ini teler ya, ini anak buah kita itu susah untuk kita, kita kita harapkan trengginas Pak. Mesti mesti akan teler semua. Walaupun sakit-sakit, misalnya. Awake loro kabeh, itu ya kita seakan-akan ora loro kabeh sehat terus, Pak. 'Bapak-bapak ini kan pimpinan, sama dengan kita-kita ini. Pimpinan itu kan dicontoh. Kalau kita ini teler ya, ini anak buah kita itu susah untuk kita, kita kita harapkan cekatan Pak. Mesti mesti akan teler semua. Walaupun sakit-sakit, misalnya. Badannya sakit semua, itu ya kita seakan-akan tidak sakit semua sehat terus, Pak.' These utterances infered that the $d a^{\prime} i$ indirectly expressed the speech act of suggestion. The illocutionary force of suggestion observable by paying attention to the related contexts of use.

\section{Discussion}

On the basis of data classification, the speech acts of suggestion were expressed as much as 59 utteraces. The subject of speech acts suggestion on the above elaborated data can be distinguished into 6 types, among others are the imperative, option, impersonal, heding, and hint. What is interesting to note further is how the frequency of those five types of speech act suggestion. After having input the data into tabulation, table 1 below illustrates how the frequencies concerning the realization of speech act suggestion.

Tabel I. Frequecy on the use of speech act suggestion

\begin{tabular}{|r|l|c|r|}
\hline No & Realization & In numbers & Percentage \\
\hline 1 & Imperative & 25 & $42 \%$ \\
\hline 2 & $\begin{array}{l}\text { Giving } \\
\text { optionality }\end{array}$ & 11 & $19 \%$ \\
\hline 3 & Impersonal & 14 & $24 \%$ \\
\hline 4 & Hedging & 4 & $7 \%$ \\
\hline 5 & Hint & 5 & $8 \%$ \\
\hline & Total & 59 & $100 \%$ \\
\hline
\end{tabular}

The table above shows that the first form is mostly used instead of the second, third, fourth and fifth forms. In other words, most $d a^{\prime} i(\mathrm{~s})$ prefer direct form in giving speech act of suggestion. This finding is in line with that stated by Thomas (1996) that the realization of speech acts is not directly influenced by several aspects and one of them is the aspect of power. In the context of dialogical da'wah in the city of Surakarta, the expert powe) that turned the $d a^{\prime} i$ prefer the first form on expressing the speect act of suggestion. The second form to the fifth form is a form that can be categorized as a polite form of expressing messages. The second form to this fourth form if we were to observe from the theory of Brown and Levinson (1987), it can be categorized as an effort of mitigating the mad'u(s) face by observing linguistic strategies of negative politeness. Meanwhile, the fifth form can be incorporated into the use of vague strategies. The second form to the fourth can be referred that speaker's effort to honor the mad'u as well as to save his/her face image. On the fifth form, the use of cues or hints found only in a small frequency of use due to factors in understanding this case. Although it seems more polite, however, the time factor needed to understand the illocutionary for a long period of time, that can lead the $d a$ ' $i$ to slightly use this form. It seems that the costly and risky factors, are unconsciously considered a $d a^{\prime} i$ on using the fifth form.

\section{V.CONCLUSION}

One of the answers given at the time responding to the mad'u question, it is a suggested act of speech. The findings were obtained through realizing the speech acts of suggesting into five forms, namely imperative form, in the form of providing options, impersonal forms, hedging, and hints. The first form was widely used because of the power factor possessed by experts in the field of religion. Meanwhile, the second form to the fifth form was used due to the desire of $d a^{\prime} i$ to reduce the degree of facial threat to the $\operatorname{mad}^{\prime} u$. 


\section{References}

Atmawati, Dwi. (2002). Register dakwah: studi kasus dakwah Islam oleh K.H. Zainudin, M.Z.: Kajian Sosiolinguistik. (Tesis). Program Studi LInguistik Jurusan Ilmu-Ilmu Humaniora. Universitas Gadjah Mada.

Atmawati, Dwi. (2009). Wacana dakwah beberapa dai/daiyah terkemuka di Indonesia. (Disertasi). Program Studi Linguistik Fakultas Ilmu Budaya Universitas Gadjah Mada.

Austin, J.L. (1962). How to do things with words. Cambridge Mass: Harvard University Press.

Brown, Penelope dan Stephen Levinson. (1987). Politeness Some Universal in Language Usage. Cambridge: Cambridge University Press.

Gusneti. (2007). Penggunaan bahasa mubaligh dalam pengajian ramadhan di mesjid cahaya rohani pasir sebelah padang: suatu tinjauan sosiolinguistik. Dalam Kongres Linguistik Nasional XII. Surakarta, 3-6 September 2007.

Hadisaputra, Widada. (1994). gejala interferensi dalam bahasa Jawa: studi bentuk tuturan khotbah agama Islam. Dalam Jurnal Jala Bahasa. Jakarta: Pusat Bahasa Departemen Pendidikan Nasional.

Hidayat, Dudung Rahmat. (1999). Pemakaian bahasa Indonesia ragam lisan oleh para khotib di kotamadya Bandung: studi deskriptif terhadap ragam dan fungsi bahasa. (Tesis). Bandung: Program Pascasarjana Universitas Pendidikan Indonesia.

Irawati, Lydia, (2004). Interferensi bahasa Sunda pada dakwah bahasa Indonesia K.H. Abdullah Gymnastiar (Aa Gym). Dalam Metalingua, 2(1) Juni 2004. Bandung: Balai Bahasa Bandung.

Leech, Geoffrey. (1983). The principles of pragmatics. New York: Longman Group Limited.

Maksan, Marjusman. (2001). Alih kode dalam pengajian Ramadan. Dalam Linguistik Indonesia. Jakarta: MLI dan Yayasan Obor Indonesia.

Ma'ruf, Amir. (1999). Wacana khotbah Jumat: studi kasus empat masjid di Yogyakarta. (Tesis). Yogyakarta: Universitas Gadjah Mada.

Saddhono, Kundaru. (2005). Analisis wacana khotbah Jumat: pendekatan mikrostruktural dan makrostruktural. (Laporan Penelitian). Universitas Sebelas Maret.

Sadhono, Kundaru. (2011). Wacana khotbah Jumat di kota Surakarta sebuah kajian sosiopragmatik. (Disertasi). Program Pascasarjana Fakultas Ilmu Budaya Universitas Gadjah Mada.

Searle, John R. (1979). A taxonomy of illocutionary acts. Dalam A.P. Martinich (ed). 1996. The Philosophy of Language. New York dan Oxford: Oxford University Press.

Subagyo, P. Ari. (2000). Alih kode sebagai salah satu kunci sukses ceramah K.H. Zainudin, M.Z. Dalam Jurnal Lembaga Penelitian Universitas Sanata Dharma. Yogyakarta: Universitas Sanata Dharma.
Sudaryanto. (1993). Metode dan aneka teknik analisis bahasa: pengantar penelitian wahana kebudayaan secara linguistis. Yogyakarta: Duta Wacana Press.

Thomas, Jeny. (1996). Meaning in interaction. London/New York: Longman. 